\title{
Chemical Speciation and Mobility Factors of Heavy Metals in Soil Around an Integrated Steel Complex Communities
}

\author{
M. A. Balogun ${ }^{1 *}$, S. H. O. Egboh $^{2}$ and M. O. Money-Irubor ${ }^{3}$ \\ ${ }^{1}$ Department of Chemistry, College of Education, Warri, Delta State \\ ${ }^{2}$ Department of Chemistry, Delta State University, Abraka, Delta State \\ ${ }^{3}$ Department of Integrated Science, College of Education, Warri, Delta State \\ *Correspondence author: Balogunadebayo2007@gmail.com \\ Received 07 November 2020; accepted 27 February 2021, published online 30 March 2021
}

\begin{abstract}
Some heavy metals, consisting of $\mathrm{Fe}, \mathrm{Cd}, \mathrm{Co}, \mathrm{Cu}, \mathrm{Mn}, \mathrm{Ni}, \mathrm{Pb}$ and $\mathrm{Zn}$ were determined using USEPA Method 3050B for total metal concentration. Six composite samples were located from Aladja (ALJ), Ovwian (OVW), Ejevwu (EJW), Ekete Inland (EKI\}, Orhuwhorun (ORH), and Otor-Udu (OTU) towns. In addition, chemical speciation was carried out on these samples using method employed by Tessier $e t$ $a l$. as modified by Kersten and Forstner to assess their speciation pattern and the fraction of abundance as determinant of environmental pollution. From the results obtained, concentrations of $\mathrm{Fe}, \mathrm{Cd}$ and $\mathrm{Mn}$ were more predominant in the residual fraction $\left(\mathrm{F}_{5}\right)$ in the form of $\mathrm{Fe}^{3+}, \mathrm{Cd}^{2+} \mathrm{Mn}^{2+}$ respectively for both wet and dry seasons. Co was more in the exchangeable fraction $\left(\mathrm{F}_{1}\right)$ as $\mathrm{Co}^{2+}$ for both seasons. Concentration of $\mathrm{Cu}$ in the form of $\mathrm{Cu}^{2+}$ is higher in Fe-Mn oxide fraction $\left(\mathrm{F}_{3}\right)$ for wet season and dry season's organic fraction $\left(\mathrm{F}_{4}\right) . \mathrm{Pb}$ and $\mathrm{Zn}$ were abundant in $\mathrm{Fe}-\mathrm{Mn}$ oxide fraction $\left(\mathrm{F}_{3}\right)$ for both seasons as divalent ions. Mobility factor calculated for the metals shows pattern in the order: $\mathrm{Pb}>\mathrm{Co}>\mathrm{Zn}>\mathrm{Mn}>$ $\mathrm{Fe}>\mathrm{Cd}>\mathrm{Cu}>\mathrm{Ni}$ for wet season and $\mathrm{Co}>\mathrm{Zn}>\mathrm{Mn}>\mathrm{Cu}>\mathrm{Pb}>\mathrm{Ni}>\mathrm{Cd}>\mathrm{Fe}$ for dry season; which is as a result of changes in some physiochemical parameters such as acidity, $\mathrm{pH}$, among others. From this result, there is the need to ensure that future health catastrophe is averted from the accumulation and release of $\mathrm{Pb}^{2+}, \mathrm{Zn}^{2+}, \mathrm{Co}^{2+}$ and $\mathrm{Mn}^{2+}$ especially into the environment.
\end{abstract}

Keywords: Sequential extraction, heavy metals, mobility factor

\section{Introduction}

Industrial processes are one of the main reasons why the world development is faster. It resulted in industrial revolution and propelled some countries to become developed within a very short period. Most countries in Asia fall into this category. China, Korea, Thailand and Malaysia are good examples of where industrial processes culminated in industrial revolution. However, it brings about some negative effects such as pollution, over population, to mention but a few, which can be very devastating. Formation of fog in many industrialised countries resulting from emission discharge in some countries such as India, China, most Asian countries is of great concern and is one of the adverse effects of industrialisation. This is more prominent in the coastal regions of Lagos, Port Harcourt, Warri, Eket and Calabar due to their easy accessibility to the ocean in the transportation of raw materials and goods $[1,2$, 3].

Pollution through continuous point source, line sources and area sources are the three main ways of contaminating the environment. Usually, all these phenomena apply in integrated plants such as Delta Steel Complex (DSC) at Ovwian-Aladja; Warri Refining and Petrochemical Company (WRPC) at Warri both in Delta State. Ajaokuta Steel Project (ASP) and Dangote Cement Company at Obajana, both in Kogi State; and Jebba Paper Mill in Kwara State, to mention but a few. Heavy metal pollution to the environment is usually through atmospheric, gravitational and mechanical transportation. All these means of transportation are embedded in the aforesaid phenomenon. This in addition makes some industries and their areas suitable location for studying the extent of heavy metal contamination to the soils and crops within $[5,6,14]$.

\section{Materials and methods}

Soil samples analysed were collected from six different settlements, in both wet and dry seasons. Picking of collection points was aided through the utilization of physical identification of houses or a unique structure and Geological 
Position System (GPS) equipment. The soil samples were collected from a dept of $0-12$ inches. Three different samples were collected at each point with a clean plastic spoon into clean transparent polythene bags. The three samples from each sample point were mixed to obtain a composite sample for each sample point. The sample points, which are communities within the suburb of an integrated steel plant and associated small scale industrial activities are Aladja (ALJ) (Lat. $5^{\mathrm{O}} 54765^{\prime} \mathrm{N}$, Long. $\left.5^{\mathrm{O}} 7478, \mathrm{E}\right)$; Ovwian (OVW) (Lat. $5^{\mathrm{O}} 507579^{\prime} \mathrm{N}$, Long. 5 ${ }^{\mathrm{O}} 587463^{\prime}$ E); Ejevwu (EJW) (Lat. 5 $479044^{\prime}$ N, Long. 5 ${ }^{\mathrm{O}} 770991^{\prime}$ ' E); Ekete Inland (EKI) (Lat. 5'493483' N, Long. $5^{\circ} 825236^{\prime}$ E); Orhuwhorun (ORH) (Lat. $5^{\mathrm{O}} 506213^{\prime} \mathrm{N}$, Long. $5^{\mathrm{O}} 806^{\prime} \mathrm{E}$ ); and OtorUdu (OTU) (Lat. 5 $454641^{\circ}$ N, Long. 5 $8686^{\circ}$ E). Reagents employed in this analysis are products of M\&B and BDH of England, Merck Darmstadt GMBH from Germany; and Fluka \& Riedel-de Haen GMBH, also from Germany. The soil samples were devoid of any form of unwanted substances; oven dried at $105^{\circ} \mathrm{C}$, sieved and grinded. $1.00 \mathrm{~g}$ of the prepared composite sample was measured and digested using USEPA Method 3050B [15]. Speciation of composite samples were carried out using method employed by Tessier et al. as modified by Kersten and Forstner [4, 16]. Six fractions were prepared from each sample to carry out detail evaluation of the effect of the steel complex discharges on the environment.

The fractions utilised was fraction $1\left(\mathrm{~F}_{1}\right)$, which is the exchangeable fraction. This was prepared by using $1.00 \mathrm{~g}$ of dry soil sample from composite sample collected from the various sample points. Fraction $2\left(\mathrm{~F}_{2}\right)$, which is the carbonate fraction, were prepared from the residues obtained from $F_{1}$ preparation. Fraction $3\left(\mathrm{~F}_{3}\right)$, known as the $\mathrm{Fe}-\mathrm{Mn}$ oxide fractions, were prepared from the residues obtained from fraction 2. Fraction $4\left(\mathrm{~F}_{4}\right)$, which is the organic fraction, were prepared from the residues obtained from fraction 3 also known as $\mathrm{F}_{3}$; and finally, fraction $5\left(\mathrm{~F}_{5}\right)$ known as the residual fraction, were prepared from residues obtained from organic fraction, that is $\mathrm{F}_{4}[4,16]$.

\section{Results and discussion}

Table 1: Results of sequential extraction, expressed in ppm

\begin{tabular}{cccccccc|cccccc}
\hline & & \multicolumn{6}{c|}{ Wet Season } & \multicolumn{6}{c}{ Dry Season } \\
\cline { 2 - 14 } Element & Fractions & ALJ & OVW & EJW & EKI & ORH & OUT & ALJ & OVW & EJW & EKI & ORH & OUT \\
\hline Fe & $\mathrm{F}_{1}$ & 26.68 & 10.07 & 9.59 & 9.74 & 9.79 & 9.63 & 35.82 & 17.15 & 14.91 & 15.11 & 13.47 & 7.31 \\
& $\mathrm{~F}_{2}$ & 34.25 & 23.99 & 13.29 & 15.64 & 14.07 & 9.85 & 57.78 & 21.59 & 25.43 & 27.59 & 14.05 & 9.25 \\
& $\mathrm{~F}_{3}$ & 55.38 & 12.21 & 14.97 & 2.84 & 17.01 & 13.17 & 77.43 & 27.53 & 7.68 & 29.57 & 21.81 & 12.01 \\
& $\mathrm{~F}_{4}$ & 85.18 & 45.55 & 23.57 & 28.65 & 25.22 & 18.35 & 123.2 & 40.25 & 49.25 & 45.25 & 30.87 & 23.32 \\
& $\mathrm{~F}_{5}$ & 97.79 & 61.54 & 32.56 & 37.65 & 34.15 & 21.55 & 146.2 & 63.86 & 56.39 & 52.86 & 36.04 & 28.38 \\
& $\begin{array}{c}\text { Total } \\
\text { sum of } \\
\text { fractions }\end{array}$ & 299.3 & 153.4 & 93.98 & 94.52 & 100.24 & 72.55 & 440.5 & 170.38 & 153.7 & 170.4 & 116.24 & 80.27 \\
\hline Cd & $\mathrm{F}_{1}$ & 0.02 & 0.01 & 0.01 & 0.01 & 0.02 & 0.01 & 0.04 & 0.01 & 0.02 & 0.02 & 0.02 & 0.02 \\
& $\mathrm{~F}_{2}$ & 0.04 & 0.04 & 0.02 & 0.06 & 0.06 & 0.05 & 0.16 & 0.03 & 0.03 & 0.03 & 0.03 & 0.06 \\
& $\mathrm{~F}_{3}$ & 0.04 & 0.05 & 0.05 & 0.11 & 0.1 & 0.07 & 0.18 & 0.05 & 0.06 & 0.06 & 0.07 & 0.09 \\
& $\mathrm{~F}_{4}$ & 0.03 & 0.03 & 0.03 & 0.01 & 0.03 & 0.01 & 0.05 & 0.03 & 0.02 & 0.02 & 0.02 & 0.03 \\
& $\mathrm{~F}_{5}$ & 0.12 & 0.08 & 0.06 & 0.12 & 0.11 & 0.09 & 0.34 & 0.06 & 0.08 & 0.09 & 0.08 & 0.11 \\
& Total & & & & & & & & & & & & \\
& sum of & 0.25 & 0.21 & 0.17 & 0.31 & 0.32 & 0.23 & 0.77 & 0.18 & 0.21 & 0.22 & 0.22 & 0.31 \\
\hline fractions & & & & & & & & & & & & \\
\hline Co & $\mathrm{F}_{1}$ & 9.63 & 2.32 & 1.78 & 0.59 & 0.53 & 1.49 & 21.44 & 2.21 & 2.15 & 1.86 & 1.97 & 1.69 \\
& $\mathrm{~F}_{2}$ & 1.65 & 0.32 & 0.26 & 0.63 & 0.77 & 0.49 & 3.26 & 0.72 & 0.29 & 0.25 & 0.26 & 0.55 \\
& $\mathrm{~F}_{3}$ & 4.15 & 0.79 & 1.36 & 1.11 & 1.18 & 0.99 & 4.93 & 1.18 & 1.16 & 1.04 & 1.02 & 0.23 \\
& $\mathrm{~F}_{4}$ & 2.23 & 0.45 & 0.58 & 0.68 & 0.84 & 0.82 & 1.67 & 0.29 & 0.69 & 0.61 & 0.62 & 0.91
\end{tabular}


J. Chem. Soc. Nigeria, Vol. 46, No.2, pp 0330 - 0335 [2021]

\begin{tabular}{|c|c|c|c|c|c|c|c|c|c|c|c|c|c|}
\hline & $\begin{array}{c}\mathrm{F}_{5} \\
\text { Total } \\
\text { sum of } \\
\text { fractions }\end{array}$ & 6.92 & 1.23 & 0.99 & 1.56 & 4.75 & 0.19 & $\begin{array}{c}4.17 \\
35.47\end{array}$ & 1.49 & 1.48 & 5.02 & 1.25 & 4.54 \\
\hline \multirow[t]{6}{*}{$\mathrm{Cu}$} & $\mathrm{F}_{1}$ & 0.57 & 0.09 & 0.07 & 0.07 & 0.09 & 0.05 & 1.25 & 0.14 & 1.14 & 0.78 & 0.29 & 0.65 \\
\hline & $\mathrm{F}_{2}$ & 0.85 & 0.66 & 0.71 & 0.66 & 0.69 & 0.32 & 2.58 & 1.06 & 1.02 & 1.27 & 0.79 & 1.35 \\
\hline & $\mathrm{F}_{3}$ & 2.57 & 1.73 & 1.73 & 1.55 & 1.81 & 0.86 & 0.27 & 1.09 & 0.14 & 0.22 & 1.34 & 1.16 \\
\hline & $\mathrm{F}_{4}$ & 1.59 & 0.79 & 0.64 & 0.69 & 0.77 & 0.31 & 3.94 & 2.39 & 3.03 & 3.25 & 2.58 & 0.56 \\
\hline & $\mathrm{F}_{5}$ & 0.75 & 0.47 & 0.51 & 0.47 & 0.41 & 0.21 & 0.94 & 0.39 & 0.44 & 1.25 & 0.57 & 0.52 \\
\hline & $\begin{array}{c}\text { Total } \\
\text { sum of } \\
\text { fractions }\end{array}$ & 6.33 & 3.74 & 3.66 & 3.44 & 3.77 & 1.75 & 8.98 & 5.07 & 5.77 & 6.77 & 5.57 & 4.24 \\
\hline \multirow[t]{6}{*}{ Mn } & $\mathrm{F}_{1}$ & 11.79 & 13.67 & 9.79 & 9.22 & 10.41 & 2.57 & 12.29 & 12.33 & 15.57 & 14.79 & 9.97 & 2.68 \\
\hline & $\mathrm{F}_{2}$ & 18.59 & 13.16 & 12.95 & 10.56 & 12.35 & 12.95 & 39.95 & 21.18 & 21.85 & 18.96 & 18.75 & 9.29 \\
\hline & $\mathrm{F}_{3}$ & 52.27 & 15.84 & 12.37 & 12.27 & 14.25 & 11.65 & 34.02 & 19.78 & 15.21 & 10.88 & 13.57 & 19.38 \\
\hline & $\mathrm{F}_{4}$ & 15.59 & 14.84 & 19.39 & 12.65 & 11.31 & 10.83 & 27.76 & 20.68 & 18.29 & 11.57 & 11.86 & 13.27 \\
\hline & $\mathrm{F}_{5}$ & 57.54 & 25.85 & 21.27 & 19.85 & 20.42 & 7.55 & 71.73 & 30.59 & 24.35 & 19.57 & 25.57 & 10.55 \\
\hline & $\begin{array}{c}\text { Total } \\
\text { sum of } \\
\text { fractions }\end{array}$ & 155.8 & 83.36 & 75.77 & 64.55 & 68.74 & 45.55 & 185.8 & 104.56 & 95.27 & 75.77 & 78.72 & 55.17 \\
\hline \multirow[t]{6}{*}{$\mathbf{N i}$} & $\mathrm{F}_{1}$ & 0.07 & 0.07 & 0.07 & 0.06 & 0.11 & 0.06 & 0.34 & 0.13 & 0.13 & 0.18 & 0.21 & 0.12 \\
\hline & $\mathrm{F}_{2}$ & 0.04 & 0.04 & 0.03 & 0.04 & 0.05 & 0.04 & 0.08 & 0.08 & 0.07 & 0.13 & 0.15 & 0.07 \\
\hline & $\mathrm{F}_{3}$ & 0.13 & 0.13 & 0.11 & 0.27 & 0.22 & 0.09 & 0.39 & 0.16 & 0.16 & 0.24 & 0.27 & 0.14 \\
\hline & $\mathrm{F}_{4}$ & 0.03 & 0.03 & 0.03 & 0.04 & 0.03 & 0.03 & 0.55 & 0.04 & 0.04 & 0.05 & 0.06 & 0.04 \\
\hline & $\mathrm{F}_{5}$ & 0.41 & 0.37 & 0.34 & 0.41 & 0.37 & 0.33 & 0.19 & 0.33 & 0.32 & 0.44 & 0.43 & 0.22 \\
\hline & $\begin{array}{c}\text { Total } \\
\text { sum of } \\
\text { fractions }\end{array}$ & 0.68 & 0.64 & 0.58 & 0.82 & 0.78 & 0.55 & 1.55 & 0.74 & 0.72 & 1.04 & 1.12 & 0.59 \\
\hline \multirow[t]{6}{*}{$\mathbf{P b}$} & $\mathrm{F}_{1}$ & 3.65 & 3.14 & 6.14 & 3.63 & 6.33 & 2.55 & 5.74 & 3.99 & 4.36 & 3.97 & 5.31 & 0.77 \\
\hline & $\mathrm{F}_{2}$ & 2.85 & 1.37 & 2.27 & 1.87 & 2.27 & 1.42 & 2.15 & 1.95 & 1.53 & 1.54 & 2.15 & 1.89 \\
\hline & $\mathrm{F}_{3}$ & 7.57 & 5.36 & 3.07 & 6.75 & 4.74 & 4.56 & 10.54 & 7.67 & 6.75 & 6.21 & 8.35 & 7.78 \\
\hline & $\mathrm{F}_{4}$ & 1.25 & 0.96 & 0.97 & 1.54 & 1.93 & 1.29 & 2.58 & 0.78 & 2.15 & 1.88 & 2.45 & 1.76 \\
\hline & $\mathrm{F}_{5}$ & 3.24 & 2.54 & 3.42 & 1.95 & 2.65 & 2.02 & 4.77 & 3.37 & 3.47 & 3.19 & 4.28 & 3.57 \\
\hline & $\begin{array}{c}\text { Total } \\
\text { sum of } \\
\text { fractions }\end{array}$ & 18.56 & 13.37 & 15.87 & 13.74 & 17.92 & 11.84 & 25.78 & 17.76 & 18.26 & 16.79 & 22.54 & 15.77 \\
\hline \multirow[t]{6}{*}{$\mathbf{Z n}$} & $\mathrm{F}_{1}$ & 0.86 & 0.82 & 0.82 & 0.83 & 0.85 & 0.42 & 2.79 & 0.99 & 0.97 & 0.99 & 0.93 & 0.09 \\
\hline & $\mathrm{F}_{2}$ & 1.95 & 1.42 & 1.43 & 1.07 & 1.15 & 0.63 & 3.54 & 2.24 & 1.76 & 1.47 & 1.99 & 0.73 \\
\hline & $\mathrm{F}_{3}$ & 7.33 & 2.76 & 3.56 & 2.56 & 2.81 & 1.29 & 8.34 & 1.22 & 3.45 & 3.15 & 3.19 & 1.47 \\
\hline & $\mathrm{F}_{4}$ & 1.08 & 0.65 & 0.65 & 0.67 & 0.64 & 0.37 & 2.12 & 1.07 & 0.88 & 0.76 & 0.19 & 0.42 \\
\hline & $\mathrm{F}_{5}$ & 1.13 & 0.23 & 0.52 & 0.51 & 0.53 & 0.27 & 1.66 & 1.64 & 0.68 & 0.59 & 0.66 & 0.82 \\
\hline & $\begin{array}{c}\text { Total } \\
\text { sum of } \\
\text { fractions }\end{array}$ & 12.35 & 5.88 & 6.92 & 5.64 & 5.98 & 2.98 & 18.45 & 7.16 & 7.74 & 6.96 & 6.96 & 3.53 \\
\hline
\end{tabular}


Result obtained for iron shows that for both wet and dry seasons the residual fractions $\left(\mathrm{F}_{5}\right)$ are in abundant, while the exchangeable fractions $\left(F_{1}\right)$ have the lowest concentration from all the six sample sites. Result also shows that the iron three ion $\left(\mathrm{Fe}^{3+}\right)$ is main specie found in the residual samples. This agrees with the findings of some researchers $[2,8,10,11,12]$.

Result obtained for cadmium shows that for both wet and dry seasons the residual fractions $\left(\mathrm{F}_{5}\right)$ are in abundant, while the exchangeable fractions $\left(F_{1}\right)$ have the lowest concentration from all the six sample sites. The results obtained also shows that cadmium two ion $\left(\mathrm{Cd}^{2+}\right)$ specie is what was present in the $\mathrm{F}_{5}$ fractions. The results obtained are consistent with that of some researchers $[2,8,10,11,12]$. Cobalt analysis for fractions shows that for both wet and dry season the exchangeable fractions $\left(\mathrm{F}_{1}\right)$ in the form of cobalt two ion $\left(\left(\mathrm{Cd}^{2+}\right)\right.$ are in abundant, while the organic fractions $\left(\mathrm{F}_{4}\right)$ have the lowest concentration from all the six sample sites. Results also shows that cobalt two ion $\left(\mathrm{Co}^{2+}\right)$ is the dominant specie. The results obtained are consistent with that of some researchers $[2,8,10,11,12]$.

Result obtained for copper analysis for speciation shows that for wet season, the Fe-Mn fractions was in abundant, while for dry season the organic fractions was in abundant for all the sample points. Result also shows that the exchangeable fractions $\left(F_{1}\right)$ have the lowest concentration from all the sample sites for both wet and dry seasons. Results also shows that copper two ion $\left(\mathrm{Cu}^{2+}\right)$ is the dominant specie, which agrees with some findings of some researchers $[2,8,10,11,12]$.

Result obtained for manganese shows that for both wet and dry seasons the residual fractions
$\left(\mathrm{F}_{5}\right)$ was in abundant, while the exchangeable fractions $\left(\mathrm{F}_{1}\right)$ have the lowest concentration from all the six sample sites. The results obtained also shows that manganese two ion $\left(\mathrm{Mn}^{2+}\right)$ specie is what was present in the $\mathrm{F}_{5}$ fractions, which is consistent with some findings $[2,8,10,11,12]$.

Result obtained for nickel shows that for both wet and dry seasons the residual fractions $\left(\mathrm{F}_{5}\right)$ are in abundant, while the exchangeable fractions $\left(\mathrm{F}_{1}\right)$ have the lowest concentration from all the six sample sites. The results obtained also shows that manganese two ion $\left(\mathrm{Ni}^{2+}\right)$ specie is what is present in the $\mathrm{F}_{5}$ fractions. This agrees with some findings $[2,8$, $10,11,12]$.

Result obtained for lead shows that for both wet and dry seasons the Fe-Mn fractions $\left(\mathrm{F}_{3}\right)$ were in abundant, while the organic fractions $\left(\mathrm{F}_{4}\right)$ were of lower concentrations in all the samples, from the six sample sites. Results obtained also shows that lead two ion $\left(\mathrm{Pb}^{2+}\right)$ specie is in the dominant form. Which is also corroborated by some findings $[2,8,10,11,12]$.

Result obtained for zinc shows that for both wet and dry seasons the Fe-Mn fractions $\left(\mathrm{F}_{3}\right)$ were in abundant, while the residual fractions $\left(\mathrm{F}_{5}\right)$ were of lower concentrations in all the samples, from the six sample sites. Results obtained also shows that zinc two ion $\left(\mathrm{Zn}^{2+}\right)$ specie is in the dominant form. This agrees with some findings of some researchers $[2,8,10,11,12]$.

\section{Determination of mobility factor}

Mobility factor is determined using the values obtained for speciation analysis. The usual formula for its calculation is the sum of $F_{1}$ and $\mathrm{F}_{2}$ divided by the total sum of all the fractions $\left(F_{1}+F_{2}+F_{3}+F_{4}+F_{5}\right)$, multiplied by $100[2,8$, $10]$.

$$
\text { Mobility Factor }=\frac{F 1+F 2}{F 1+F 2+F 3+F 4+F 5} \quad X 100
$$

where: $\quad F_{1}=$ Exchangeable metal content fraction

$\mathrm{F}_{2}=$ Metal content bound to carbonate fraction

$\mathrm{F}_{3}=$ Metal content bound to Fe-Mn oxide fraction

$\mathrm{F}_{4}=$ Metal content bound to organic matter fraction

$\mathrm{F}_{5}=$ Residual metal content fraction 
J. Chem. Soc. Nigeria, Vol. 46, No.2, pp 0330 - 0335 [2021]

Table 2: Values obtained for mobility factor of heavy metals under study

\begin{tabular}{cccccccc}
\hline & & \multicolumn{6}{c}{ Sampling Zones } \\
\cline { 3 - 7 } Metals & Season & ALJ & OVW & EJW & EKI & ORH & OUT \\
\hline Fe & Wet & 20.36 & 22.21 & 24.35 & 26.85 & 23.8 & 26.85 \\
& Dry & 21.25 & 22.74 & 26.25 & 25.06 & 23.68 & 20.63 \\
Cd & Wet & 24.00 & 23.81 & 17.65 & 22.58 & 25.00 & 26.09 \\
& Dry & 25.97 & 22.22 & 23.81 & 22.73 & 22.73 & 25.81 \\
Co & Wet & 45.89 & 51.66 & 41.05 & 26.7 & 27.37 & 49.75 \\
& Dry & 69.64 & 49.75 & 42.29 & 42.03 & 43.55 & 49.34 \\
Cu & Wet & 22.43 & 20.05 & 21.31 & 21.22 & 20.69 & 21.14 \\
& Dry & 42.65 & 23.67 & 37.44 & 30.28 & 19.39 & 47.17 \\
Mn & Wet & 19.50 & 32.19 & 30.01 & 30.64 & 33.11 & 34.07 \\
& Dry & 28.12 & 32.05 & 39.28 & 44.54 & 36.48 & 21.7 \\
Ni & Wet & 16.18 & 17.19 & 17.24 & 12.20 & 20.51 & 18.18 \\
& Dry & 27.1 & 28.38 & 27.78 & 29.81 & 32.14 & 32.20 \\
Pb & Wet & 35.02 & 33.73 & 52.99 & 40.03 & 47.99 & 33.53 \\
& Dry & 30.61 & 33.45 & 32.26 & 32.82 & 33.10 & 16.87 \\
Zn & Wet & 22.75 & 38.10 & 32.51 & 33.69 & 33.44 & 35.23 \\
& Dry & 34.31 & 45.11 & 35.27 & 35.34 & 41.95 & 23.23 \\
\hline
\end{tabular}

Mobility factor values calculated is as showed in Table 2. The general mobility factor for wet season as calculated shows that lead has the highest value, while nickel has the lowest value. The values obtained was in the order: $\mathrm{Pb}>\mathrm{Co}>$ $\mathrm{Zn}>\mathrm{Mn}>\mathrm{Fe}>\mathrm{Cd}<\mathrm{Cu}>\mathrm{Ni}$. The general mobility factors obtained for dry season was at variance with the one for wet season. Cobalt has the highest value, while iron was of the lowest value. It is in the order: $\mathrm{Co}<\mathrm{Zn}>\mathrm{Mn}>\mathrm{Cu}>$ $\mathrm{Pb}>\mathrm{Ni}>\mathrm{Cd}>\mathrm{Fe}$. $\mathrm{Cu}$. In both cases, the values for copper is the lowest. The result predicts the heavy metals of concern; which are lead, zinc and manganese.

\section{Conclusion}

Result obtained for chemical speciation for the various sample sites shows that cobalt is more predominant in the exchangeable fractions $\left(\mathrm{F}_{1}\right)$. Copper, lead and zinc were predominant in the Fe-Mn oxide/reducible fractions $\left(\mathrm{F}_{3}\right)$; while iron, cadmium, manganese and nickel were abundant in the residual fractions $\left(\mathrm{F}_{5}\right)$.

Furthermore, result also shows that iron, copper, manganese, cadmium and nickel were lower in exchangeable fractions $\left(\mathrm{F}_{1}\right)$; cobalt and lead lower in organic fractions $\left(\mathrm{F}_{4}\right)$; while zinc was lower in residual fractions $\left(\mathrm{F}_{5}\right)$. Of more concern are the $\mathrm{Fe}-\mathrm{Mn}$ fractions and residual fractions. This is because these bounded heavy metals can easily be released into the atmosphere; and this can cause series of problems to the environment which may have adverse effects on humans and other living organisms.

Mobility factor values obtained shows that it is higher in dry season compare to wet season.

Each sample site shows a pattern of consistency and closeness in terms of values obtained. However, Fe and $\mathrm{Mn}$ were higher in Ekete Inland samples; $\mathrm{Cd}$, $\mathrm{Co}$ and $\mathrm{Cu}$ were higher in Otor-Udu samples; $\mathrm{Co}$ and $\mathrm{Cu}$ were higher in Aladja samples; Co and $\mathrm{Zn}$ were higher on Ovwian samples; while $\mathrm{Ni}$ and $\mathrm{Pb}$ were higher in Orhuwhorun and Ejevwu samples respectively. For wet season, the mobility factor is in the order: $\mathrm{Pb}>\mathrm{Co}>\mathrm{Zn}>\mathrm{Mn}>\mathrm{Fe}>\mathrm{Cd}<$ $\mathrm{Cu}>\mathrm{Ni}$. While for dry season, the order is $\mathrm{Co}<$ $\mathrm{Zn}>\mathrm{Mn}>\mathrm{Cu}>\mathrm{Pb}>\mathrm{Ni}>\mathrm{Cd}>\mathrm{Fe}$. Result shows that $\mathrm{Pb}, \mathrm{Co}$ and $\mathrm{Zn}$ had the highest values, especially in wet season, while the values for $\mathrm{Ni}$ and $\mathrm{Fe}$ are the lowest. Thus, the need to control the release of heavy metals into the environment; especially lead, cobalt and zinc; so as to prevent environmental catastrophe in the future. 


\section{References}

1. S. H. O. Egboh and E. M. Emeshili (2007). Physico-Chemical characteristics of River

Ethiope source in Umuaja, Delta State, Nigeria. J. Chem. Soc. of Nig., 32 (2): $72-76$.

2. M. A. Balogun, M. O. Money, H. N. Omosigho and H. O. Ataikiru (2019). Pollution level determination using chemical speciation in the vicinity of petroleum prospecting areas in Southern Niger Delta. J. Chem. Soc. of Nig., 44 (5): $686-692$.

3. M. A. Balogun, H. N. Omosigho, H. O. Ukulu and M. O. Money (2019). Heavy metals

concentration in Ofuafor River, Delta State. NJAS 37: 37: 147 - 154.

4. A. Tessier, P. G. C. Campbell and M. Bisson (1979). Sequential extraction proceduresfor

the speciation of particulate trace metals. Anal. Chem., 51: 844-851.

5. E. M. Emeshili and S. H. O. Egboh (2008). Levels of heavy metals in Ucapagilator and

Drepane africana from Ase River, SouthSouth Nigeria. J. Chem. Soc. of Nig., 33 (2): 148-151.

6. B. O. Peretiemo-Clarke, M. A. Balogun and A. O. Akpojiyovwi (2009). A study of physicochemical characteristics of Ugborikoko/Okere stream as an index of pollution.

African Journal of Biotechnol., 8 (22): $6272-6276$

7. V. O. Ezigo (2012). An investigation into the heavy metals in fresh water fish species sold

in Onitsha Market, Anambra State, Nigeria. J. Chem. Soc. of Nig., 37 (2): $112-114$

8. M. Horsfall. and A. Spiff (2005). Speciation and biodiversity of heavy metals in sediments of Diobu River, Port Harcourt, Nigeria.Europ. J. Sci. Res., 6 (3): 20 -36 .

9. J. C. Igwe, P. O. Ihesilo and I. C. Nnorom (2012). Trace element analysis of forage
Samples in Niger Delta of Nigeria. J. Chem. Soc. of Nig., 37 (2): 93 - 97.

10. C. M. A. Iwegbue, G. E. Eghwrudje, G. E. Nwajei and S. H. O. Egboh (2007). Chemical speciation of heavy metals in the Ase

River, Niger Delta, Nigeria. Chem. Speciation and Bioavailability, 19 (3): 117 - 127.

11. S. A. Osakwe (2013). Chemical partitioning of iron, cadmium, nickel and chromium in

contaminated soils of south-eastern

Nigeria. Chem. Speciation and

Biodiversity. 25 (1): 71 - 78.

12. M. J. B. Segarra, R. Prego, M. J. Wilson, J. Bacon and J. S. Santos-Echeandia (2008).

Metal speciation in surface sediments of the Vigo Ria, N. W. Iberian Peninsula. Sci.

Mar., 72 (1):119-126.

13. R. K. Sharma, M. Agrawal and F. Marshall (2004). Heavy metals contamination of soil

and vegetables in suburban areas of Varanasi, India. Ecotoxical Environ. Safety J.

Doi: 10, 1016/jecenv.

14. H. S. Ukulu, M. A. Balogun, B. T. Sawere, B. T. and H. O. Chidi (2018). Analysis of heavy

metals in the catfish species; Clarias gariepinus. JCSN 43 (4): 711 - 716.

15. USEPA (1996). Acid digestion of sediments, sludge and soils: Method 3050B. USEPA;

Washington D.C., USA. 5 - 15.

16. M. Kersten and U. Forstner (1986). Chemical fractionation of heavy metals in anoxia Estuarine and coastal sediments. Water Sci. Technol., (18): $121-130$. 